\title{
PHYSICS OF NONTHERMAL RADIO SOURCES
}

NASA SP.46

\author{
$1 / 4$ Tn Bind
}

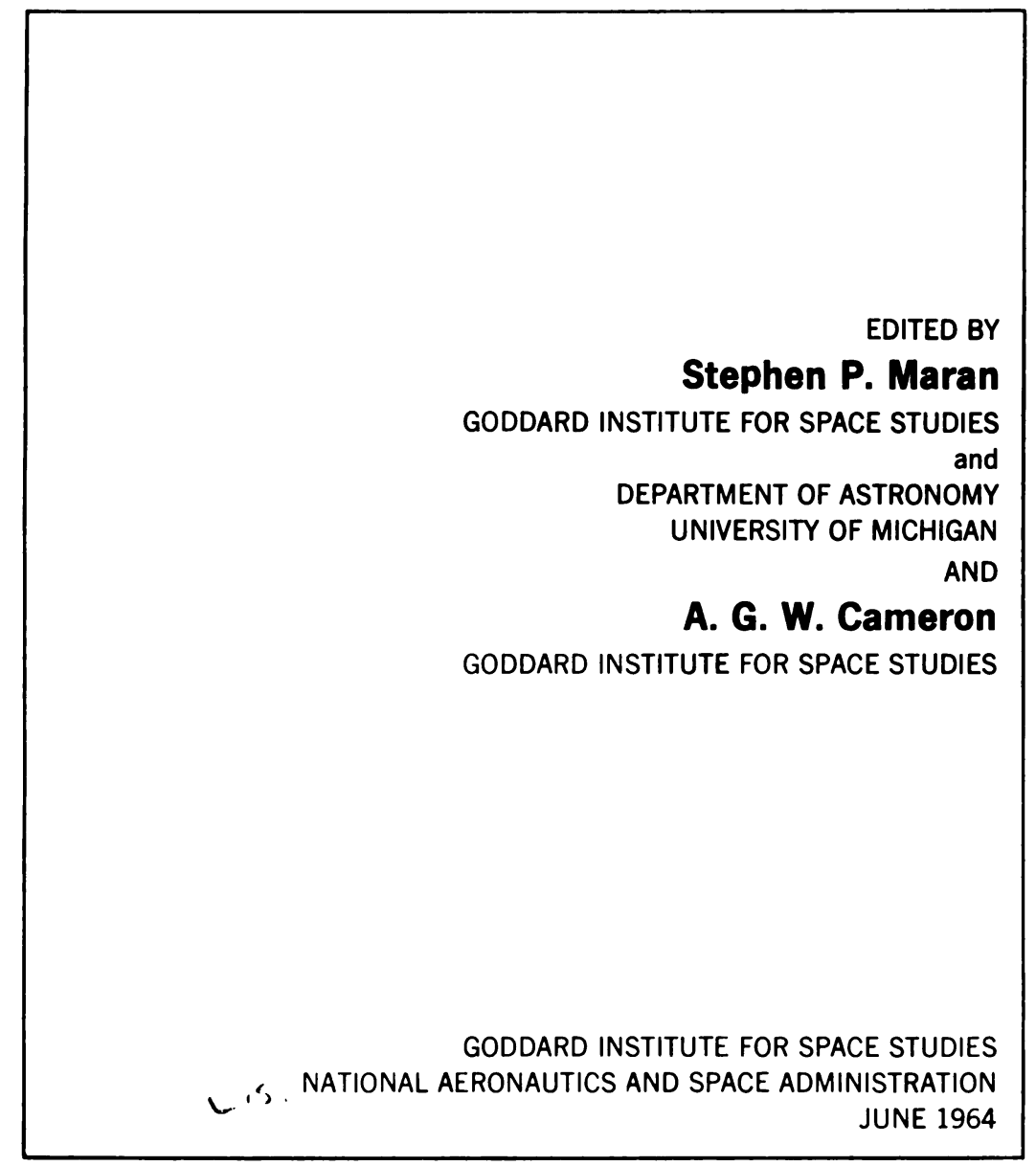

